\title{
Collective Action and Social Capital of Wildlife Management Associations
}

\author{
MATTHEW W. WAGNER, ${ }^{1}$ Texas Parks and Wildlife Department, Austin, TX 78744, USA \\ URS P. KREUTER, Department of Rangeland Ecology and Management, Texas A $\Xi M$ University, College Station, TX 77843-2126, USA \\ RONALD A. KAISER, Recreation, Parks and Tourism Sciences, Texas AEM University, College Station, TX 77843-2261, USA \\ R. NEAL WILKINS, Texas AE'M Institute of Renewable Natural Resources, College Station, TX 77843-2260, USA
}

\begin{abstract}
In areas with dense landownership patterns, management of white-tailed deer (Odocoileus virginianus) depends upon collective decision making of landowners and hunters. To resolve conflicts associated with this commons dilemma, wildlife management associations (WMAs) have become a popular mechanism for coordinating wildlife management decisions in private land states, especially in Texas, USA. Social capital, represented by metrics such as trust, reciprocity, and community involvement, has been identified as an important determinant of the success of collaborative institutional arrangements. To determine the influence of social capital on the effectiveness of WMAs, we address 2 research questions: 1) do WMAs exhibit elements of social capital, and 2) what landowner characteristics affect elements of social capital within WMAs? We used a mail survey questionnaire to determine the effect of various factors on the activities and management practices in 4 WMAs in 2 regions in Texas: the Lower Post Oak Savannah (LPOS) and the Central Post Oak Savannah (CPOS). The LPOS landowners were members of larger associations, had generally acquired their land more recently, held more frequent meetings, and tended to have longer association membership than CPOS landowners, yet they exhibited lower social capital. The CPOS landowners owned significantly larger properties, and were predominantly absentee wealthy males that considered relaxation and hunting more important land uses than property ownership for a place to live. The smaller group size of the CPOS associations may be the most important factor in building and maintaining social capital. Intra-association trust, a primary measure of social capital, was positively influenced by the longevity of property ownership, the number of association meetings, the percentage of males in the association, and other factors. Conversely, negative influences on trust included absentee ownership and the proportion of woodland habitat present in each WMA. We suggest that deer are a common-pool resource whose populations are dependent upon collective action by stakeholders. Social capital building within landowner associations could facilitate the sustainable harvest of quality deer and possibly lead to cooperative management of other common-pool natural resources. (JOURNAL OF WILDLIFE MANAGEMENT 71(5):1729-1738; 2007)
\end{abstract}

DOI: $10.2193 / 2006-199$

KEY WORDS common-pool resource, landowner associations, Odocoileus virginianus, social capital, white-tailed deer.

Deer (Odocoileus spp.) hunting in Texas, USA, is big business. Hunting opportunities in the state are inextricably linked to private landowners who manage over $98 \%$ of the rural land. These landowners provide hunting opportunities through various forms of leases, whereby hunters pay landowners a fee to access their land for a fixed number of years, or by packaged hunts. More than 8.5 million ha of the state's private lands are under such hunting enterprises (J. Rivers, Texas Parks and Wildlife Department [TPWD], unpublished report), with fees commonly ranging from $\$ 15$ to $\$ 25 / \mathrm{ha}$, or more. In prime deer habitat areas, revenue from hunting exceeds the agricultural production values from the land (Benson et al. 1999).

In addition to providing sufficient habitat, managing for quality deer hunting requires adherence to harvest criteria for males and females over a large area. Achieving balanced sex ratios while maintaining adequate mature males for harvest depends upon committed hunters following guidelines set forth by wildlife agencies and cooperation among neighboring landowners. As property size decreases, cooperation among landowners and hunters becomes more difficult, yet more important. Collective decision making may be fostered through group interaction that builds social capital, particularly trust.

Landowner cooperatives for managing wildlife resources

${ }^{1}$ E-mail: matt.wagner@tpwd.state.tx.us in the north-central United States began $>70$ years ago (Leopold 1936, 1940). Today, wildlife management associations (WMAs) can be found in $\geq 6$ other states including Colorado, Louisiana, Mississippi, Oklahoma, Vermont, and Wyoming (Hendrix 2002, Benson 2004, Dobbs 2004, Mississippi State University Extension Service 2004, Rottman and Powell 2004). The first WMA in Texas was formed in 1955 (TPWD 2004). Multilandowner groups formed to manage wildlife resources, especially white-tailed deer (O. virginianus), are of increasing importance with the number and acreage of WMAs on private land totaling about 160 on nearly 770,000 ha (TPWD 2004). Such associations operate under a written wildlife management plan often prepared by a TPWD wildlife biologist, and they vary in character, size, and organizational structure.

Wildlife associations may hold promise for the management of other natural resources that traverse private lands because they adhere to the model of mutual cooperation for mutual benefits (Hardin 1968). Under a management scenario, deer could be considered a common-pool resource because the size and quality of their population depends upon the collective action of stakeholders. Understanding the role of social capital in the cooperative management of common-pool resources on private land may lead to other public benefits including sustained water supply (Wagner and Kreuter 2004), restoration of biodiversity (Pretty and Smith 2004), and protection of scenic open spaces. 


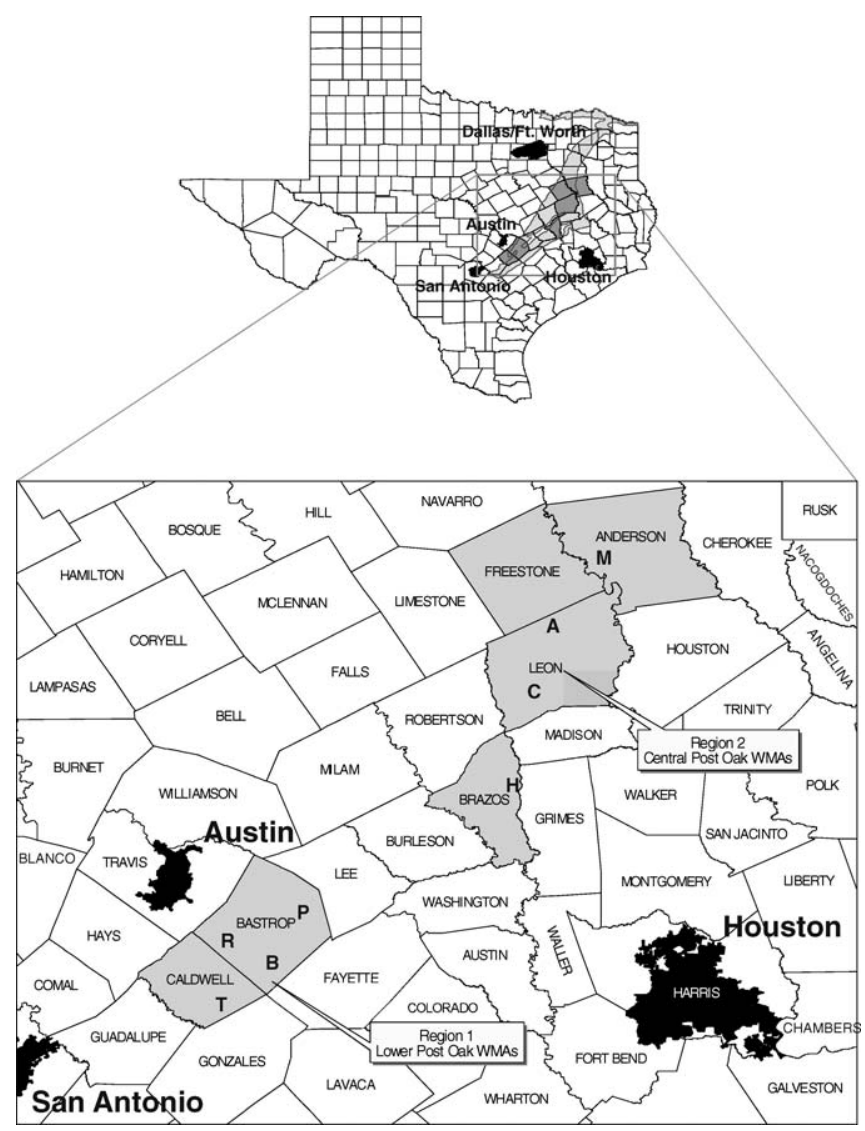

Figure 1. Locations of Lower and Central Post Oak Savannah Wildlife Management Associations (WMAs) in Texas, USA, 2004. In the Lower Post Oak Savannah (Region 1) B = Bartons Creek WMA, P = Pin Oak Creek WMA, and $\mathrm{R}=$ Red Rock WMA (Bastrop County); and $\mathrm{T}=$ TriCommunity WMA (Caldwell County). In the Central Post Oak Savanna (Region 2) $\mathrm{A}=$ Alligator Creek WMA and $\mathrm{C}=$ Clear Creek WMA (Leon County); $\mathrm{H}=$ Harvey WMA (Brazos County); and $\mathrm{M}=$ Mid Trinity Basin Conservation Cooperative (Anderson and Freestone counties).

The importance of social capital in forming voluntary associations has been widely studied by political scientists and sociologists (Coleman 1990; Putnam 1995, 1996, 2000; Flora 1998; Stolle 2001; Anheier and Kendall 2002). They refer to social capital in terms of the value of community engagement that leads to mutual benefits and cooperation. Measures of social capital include general and interpersonal trust, reciprocity, and civic participation (Coleman 1990, Tyler and Degoey 1995, Hofferth and Iceland 1998, Molm et al. 2000, Putnam 2000). Of these, trust has been demonstrated to play a key role in mediating resource consumption in commons dilemmas (Brann and Foddy 1987). Some factors affecting social capital include group size (McPherson 1983, Kerr 1989, Levine and Moreland 1990), residential stability (Putnam 1995, 2000; Hofferth and Iceland 1998; Anheier and Kendall 2002), and gender homogeneity (Levine and Moreland 1990, Putnam 2000, Halpern 2005).

Our purpose was to assess landowner characteristics and social capital within associations engaged in wildlife management in Texas. We assessed landowner demographics, habitat descriptions, and the level of land and water conservation practices performed by association members. We addressed 2 questions: 1) do WMAs exhibit elements of social capital, and 2) what landowner characteristics affect these elements of social capital within WMAs? This information could be used to gain insight into various social attributes necessary for improved management of economically important white-tailed deer in Texas, as well as other important common pool resources.

\section{STUDY AREA}

Our study area was located within the lower and central portions of the Post Oak Savannah Region of Texas (Fig. 1) located between Dallas-Fort Worth, Houston, Austin, and San Antonio in east-central Texas. This region encompassed over 6.8 million ha in 32 counties. About $55 \%$ of this area was pastureland, primarily of bermudagrass (Cynodon spp.; United States Department of Agriculture 1997). The remaining area was a combination of upland and bottomland oak (Quercus spp.) woodlands mixed with remnant native grasslands. As the population continues to grow in urban centers, the ownership sizes of surrounding rural land tracts are shrinking. In addition, while the value of agriculture production is in decline, the recreational value of rural land is increasing. Hunting, fishing, and recreation in scenic areas are major interests of city dwellers seeking an escape to the countryside. Newer landowners are increasingly interested in wildlife and habitat management, but the highly fragmented ownership patterns make management of wildlife habitat difficult. The solution has been the formation of WMAs, and the Post Oak Savannah Region has one of the highest concentrations of WMAs in the state.

Our study focused on 4 landowner associations in the Lower Post Oak Savannah (LPOS), and 4 associations in the Central Post Oak Savannah (CPOS; Fig. 1). We selected these 2 regions based upon differences in land ownership patterns and size of the local deer populations. The 4 WMAs in LPOS included Bartons Creek (BCWMA), Pin Oak Creek (POCWMA), Red Rock (RRWMA), and Tri-Community (TCWMA). The 4 WMAs in CPOS included Alligator Creek (ACWMA), Clear Creek (CCWMA), Harvey (HWMA), and Mid Trinity Basin Conservation Cooperative (MTBCC). The LPOS was characterized by smaller land tract size, higher rates of land fragmentation (Land Information Systems 2005), and lower local deer population densities (3.9 deer/ $\mathrm{km}^{2}$ compared to CPOS at about 31.7 deer $/ \mathrm{km}^{2}$; M. Longoria and M.W. Wagner, TPWD, unpublished data). In general, WMAs in LPOS were formed to increase deer numbers, in part, by importing deer from other areas of the state, while simultaneously making habitat improvements. Associations in CPOS were formed around existing high deer numbers, but low quality caused by unbalanced sex ratios and lack of mature males. We hypothesized that regional differences in tract size, number of association members, and quantity and quality of deer would affect the willingness of landowners to cooperate and the levels of social capital within the group. 


\section{METHODS}

During the autumn of 2004, we mailed a survey questionnaire to all 458 member landowners within the 4 WMAs in LPOS and 137 landowners in 4 WMAs in CPOS for a total of 595 survey participants. Our questionnaire survey followed protocols outlined by Dillman (2000) and we designed it to collect socio-demographic information on landowners, their property characteristics, and the degree of social capital they exhibited within their association. We based the questionnaire on pretested survey instruments used in Olenick et al. (2005) and Jackson-Smith et al. (2005). We divided 21 questions into the following sections: Property and Land Management Characteristics, Social Interaction and Civic Participation, and Personal Information (see Appendix for a list of questions in each category). We conducted a nonresponse bias survey for 19 landowners in 6 WMAs by phone interview of 11 questions selected from the original questionnaire (Lohr 1999, Czaja and Blair 2005).

Metrics for social capital included intra-association trust, reciprocity, and community involvement. We considered trust the primary measure since it is most commonly cited in the social capital literature (Coleman 1990, Brehm and Rahn 1997, Putnam 2000, Silverman 2004, Halpern 2005). We used a 5 -point Likert-type scale $(5=$ very positive $\ldots 1$ $=$ very negative) to obtain information about land management priorities, trust, and reciprocity. Questions about community involvement similarly included a Likert-type scale, but response values ranged from 3 (very involved) to 0 (not involved).

We created an index for landowner trust within an association by summing and averaging each respondent's level of agreement with the following 4 statements: 1) I know most members of my landowner association; 2) I meet with members outside of association activities; 3 ) There are many members I consider friends; and 4) I trust members of my landowner association. Based on the literature, we considered these statements to be indicative of the level of inter-personal familiarity and trust among landowners within an association. The Cronbach alpha reliability coefficient for the trust index was 0.831 ; values $>0.700$ generally indicate that the items in an index are reliably related to each other (Foster 2001). We similarly created an index for reciprocity by averaging respondents' level of agreement with the following 4 statements: 1) I would loan equipment to any member of my landowner association; 2) I would provide personal time to help at least one nonkin member of my association; 3) I would provide personal time to help any member of my association; and 4) I would lend money to any member of my association. The Cronbach alpha reliability coefficient for the reciprocity index was 0.737. Finally, we generated an index for community involvement for each landowner by summing their level of involvement in each of 7 community organizations plus a category for "other," with scores ranging from 0 to 24 . The Cronbach alpha coefficient for community involvement index was 0.681 .
We combined the proportions of various habitat types on each property into a Habitat Cover Index (HCI) to reflect white-tailed deer habitat. We derived this index using:

$$
\mathrm{HCI}=\mathrm{TT}+0.67 \mathrm{NR}
$$

where $\mathrm{TT}=$ percentage of total timbered habitat, and $\mathrm{NR}=$ percentage of native rangeland. We only used this simple formula to contrast coarse-scale ratios of timbered lands and open native rangelands. We combined the proportions of upland and bottomland woodlands to obtain total timbered habitat. We weighted this total most heavily (coeff. of 1) because areas of oak woodland habitats are relatively limited in the study area and considered the most important for deer since they reach their highest population densities in this habitat type (Yantis 1984). Nonnative forage represents the poorest habitat and we assigned it a coefficient of zero (Higginbotham 1999, Telfair 1999). Based on experience of local biologists, native rangelands are about two-thirds as valuable as woodlands for deer habitat.

We conducted all statistical analyses using SPSS 11.5 (SPSS, Inc., Chicago, IL). We conducted Levene's tests to check for equality of variance before mean comparisons (Daley et al. 2004). To compare the mean values of all associations within the 2 regions, we conducted $t$-tests to detect differences between paired ordinal variables, or chisquare in the case of categorical variables such as gender, education level, household income, percentage of income from property, location of primary residence, and occupation. Tract sizes and years of property ownership were highly skewed with small values producing nonnormally distributed data. To obtain normality, these variables required natural $\log (\ln )$ transformation for use in data analysis. The percentages of bottomland timber, various wildlife management activities (except rotational grazing), and association members that were related, were also nonnormally distributed due to the presence of zero values. Thus $\ln +1$ transformations were required for analyses. While we used transformed data for analyses, we present nontransformed values to facilitate interpretation. Means and standard errors are presented as follows: $\mathrm{LPOS}=\bar{x}_{\mathrm{L}}$, $\mathrm{SE}$; $\mathrm{CPOS}=\bar{x}_{\mathrm{C}}$, SE. We considered mean differences significant at $P<0.05$.

We conducted stepwise multiple regressions to identify the explanatory power of 19 independent variables for trust as the dependent variable. We organized the 19 independent variables under 4 categories: habitat, ownership, social relationships, and demographics. We present only regressions for trust for the sake of brevity and because trust is considered a primary measure of social capital within groups (MacGillivray and Walker 2000, Maloney et al. 2000, Offe and Fuchs 2002). We recoded categories for gender, primary residence, and occupation as separate dummy variables in the regressions. Variables entered the model one at a time when $P \leq 0.05$ and coefficient of determination increased and were removed when $P \geq 0.10$ and coefficient of determination decreased. We did this to explain a portion of the variability in social capital within a region as well as 
Table 1. Wildlife management associations, membership size, and survey response rate in the Post Oak Savannah Region of Texas, USA, 2004.

\begin{tabular}{|c|c|c|c|}
\hline Wildlife management association & Members & $n$ & Response rate $(\%)$ \\
\hline \multicolumn{4}{|l|}{ Lower Post Oak Savannah (LPOS) } \\
\hline Bartons Creek Game Management Association (BCWMA) & 119 & 60 & 50.4 \\
\hline Pin Oak Creek Wildlife Management Association (POCWMA) & 100 & 54 & 54.0 \\
\hline Red Rock Wildlife Management Association (RRWMA) & 148 & 79 & 53.4 \\
\hline Tri-Community Wildlife Management Association (TCWMA) & 91 & 45 & 49.5 \\
\hline Total & 458 & 238 & \\
\hline $\bar{x}$ & $115^{\mathrm{a}}$ & & 52.0 \\
\hline \multicolumn{4}{|l|}{ Central Post Oak Savannah (CPOS) } \\
\hline Alligator Creek Wildlife Management Association (ACWMA) & 6 & 5 & 83.3 \\
\hline Clear Creek Wildlife Management Association (CCWMA) & 55 & 26 & 47.3 \\
\hline Harvey Wildlife Management Association (HWMA) & 29 & 17 & 58.6 \\
\hline Mid Trinity Basin Conservation Cooperative (MTBCC) & 47 & 20 & 42.6 \\
\hline Total & 137 & 68 & \\
\hline $\bar{x}$ & $34^{\mathrm{a}}$ & & 49.6 \\
\hline
\end{tabular}

${ }^{\text {a }}$ Mean membership sizes differ significantly $(t=4.822, P=0.003)$.

within an association. The goal of the stepwise regression procedure was to generate a model of independent variables that, in combination, explained a larger portion of variability in the dependent variables than could be explained by any other combination of variables (Bryman and Cramer 1990, Babbie et al. 2003). We used the stepwise procedure only for descriptive purposes and data exploration, not for predictive purposes.

\section{RESULTS}

Of the 595 questionnaires, 306 were returned for an overall response rate of useable questionnaires of $52.0 \%$ for LPOS and $49.6 \%$ for CPOS. Response rates for individual associations ranged from $42.6 \%$ for the MTBCC (47 members) to $83.3 \%$ for the ACWMA (6 members; Table 1). Of the noncompleted questionnaires, 48 did not reach their intended landowner because of incorrect address. Twenty-eight questionnaires were returned blank or unintelligible. From the nonresponse bias survey, we did not detect any differences in age $(t=-1.017, P=0.322)$ or property size $(t=0.774, P=0.440)$, between the questionnaire respondents and phone interviewees. Occupational differences were also nonsignificant $\left(\chi^{2}=1.402, \mathrm{df}=\right.$ $2, P=0.496)$, as were differences in land-use priorities for relaxation or leisure $(t=-0.079, P=0.937)$, lease hunting $(t$ $=0.772, P=0.441)$, or number of association meetings $(t=$ $-0.299, P=0.770)$. Although both the questionnaire respondents and the phone interviewees considered wildlife management an important land-use priority ( $>4.1$ on a $5-$ point scale), phone interviewees considered wildlife management $11 \%$ less important than questionnaire respondents $(t$ $=1.877, P=0.076)$. Phone interviewees also considered livestock management $24 \%$ more important, forage production 18\% more important $(t=-6.363, P<0.001 ; t=$ $-3.357, P=0.003$, respectively), and nonlease hunting $27 \%$ less important $(t=2.183, P=0.030)$ than questionnaire respondents. Therefore, generalizations of survey data regarding these land uses would require caveats. However, we do not focus on livestock-related land use in this study, nor do we use this as a variable for explaining differences in social-capital-related metrics; trust, reciprocity, and community involvement.

\section{Respondent Demographics Between Regions}

Association membership size was $>3$ times greater in LPOS than CPOS $\left(\bar{x}_{\mathrm{L}}=115.0, \mathrm{SE}=12.6 ; \bar{x}_{\mathrm{C}}=34.0, \mathrm{SE}=10.9\right.$, $t=4.822, P=0.003)$. On average, LPOS landowners also owned about 7 times less land $\left(\bar{x}_{\mathrm{L}}=68.3 \mathrm{ha}, \mathrm{SE}=7.7\right.$; $\left.\bar{x}_{\mathrm{C}}=469.4, \mathrm{SE}=139.2, t=-8.393, P<0.001\right)$ and owned their land for about 10 years less time than CPOS landowners $\left(\bar{x}_{\mathrm{L}}=34.5, \mathrm{SE}=2.2 \mathrm{yr} ; \bar{x}_{\mathrm{C}}=44.3, \mathrm{SE}=4.7\right.$, $t=-1.745, P=0.082)$.

There was a lower percentage of male respondents in LPOS compared to CPOS $\left(\bar{x}_{\mathrm{L}}=83.2 \%, \bar{x}_{\mathrm{C}}=95.5 \%, \chi^{2}=\right.$ 6.535 , $\mathrm{df}=1, P=0.011$ ), but the percentage of related members was not different between regions, averaging $\leq 2.1 \%(t=-1.219, P=0.226)$. Mean age of landowners in associations did not differ between LPOS and CPOS $\left(\bar{x}_{\mathrm{L}}=59.8 \mathrm{yr}, \mathrm{SE}=0.8 ; \bar{x}_{\mathrm{C}}=58.3, \mathrm{SE}=1.6, t=-0.844, P=\right.$ $0.399)$.

The education level of landowners in LPOS appeared to be somewhat lower with $39.5 \%$ with a bachelors or higher degree, compared to $56.5 \%$ in CPOS (Table 2). Income data show that LPOS respondents earned less than CPOS respondents, with fewer LPOS respondents earning $>\$ 100,000$. However, we did not detect a statistically significant difference in the percentage of income derived from land activities, with $16 \%$ of the landowners in LPOS, and about $24 \%$ of the landowners in CPOS earning between $11-50 \%$ of their income from the land $\left(\chi^{2}=5.249\right.$, $\mathrm{df}=4, P=0.263)$. Slightly $>67 \%$ of LPOS members lived on their properties compared to $45 \%$ of CPOS members, a significant difference. Occupational differences between regions were not significant for those in agriculture, professional jobs, or retired.

\section{Habitat and Deer Populations}

We found no statistical differences between the 2 study areas in the percentage of total timbered habitat, native range, nonnative forage pasture, and HCI. However, the percentage of bottomland timber was on average almost 5 
Table 2. Education, income, primary residence, and occupation of landowners (\%) in wildlife management associations in the Lower Post Oak Savannah (LPOS) and Central Post Oak Savannah (CPOS) of Texas, USA, 2004.

\begin{tabular}{lcc}
\hline \multicolumn{1}{c}{ Respondent characteristic } & LPOS & CPOS \\
\hline Education & & \\
$\left.\quad \chi^{2}=9.630, \mathrm{df}=5, P=0.086\right)$ & $n=213$ & $n=62$ \\
$<$ High school & 2.3 & 0.0 \\
High school graduate & 26.8 & 22.6 \\
Vocational or technical training & 3.3 & 0.0 \\
Some college & 28.2 & 21.0 \\
Bachelor degree & 24.9 & 29.0 \\
Postgraduate degree & 14.6 & 27.4 \\
Annual income & & \\
$\left(\chi^{2}=18.002, \mathrm{df}=4, P=0.001\right)$ & $n=208$ & $n=61$ \\
$<\$ 25,000$ & 7.7 & 6.6 \\
$\$ 25,000-49,999$ & 28.8 & 21.3 \\
$\$ 50,000-74,999$ & 31.7 & 16.4 \\
$\$ 75,000-99,999$ & 16.3 & 16.4 \\
$>\$ 100,000$ & 15.4 & 39.3 \\
Primary residence & & \\
$\left.\quad \chi^{2}=10.017, \mathrm{df}=2, P=0.007\right)$ & $n=216$ & $n=60$ \\
On property & 67.1 & 45.0 \\
In town $<10,000$ & 9.3 & 13.3 \\
In urban $>10,000$ & 23.6 & 41.7 \\
Occupation & & \\
$\left.\quad \chi^{2}=1.620, \mathrm{df}=2, P=0.445\right)$ & $n=165$ & $n=49$ \\
Agriculture & 10.9 & 16.3 \\
Professional & 46.1 & 49.0 \\
Retired & 43.0 & 34.7 \\
\hline & &
\end{tabular}

times less in LPOS than CPOS $(t=-4.965, P<0.001$; Table 3). This difference can be explained by the observation that CPOS associations tended to be situated on major rivers or sizeable tributaries within the watershed, supporting a higher occurrence of bottomland hardwoods. The lower amount of bottomland timber, combined with smaller tract size, may partially explain the lower estimated deer densities in LPOS compared to CPOS. In general, as the amount of timbered habitat increased, the amount of improved pasture decreased in both study areas.

\section{Management Activities}

Nearly half the number of wildlife management activities (e.g., deer counts, selective female harvest, shallow water impoundments, feral hog control) were conducted in LPOS

Table 3. Habitat composition (\%) and Habitat Cover Index (HCI) of properties in wildlife management associations in the Lower Post Oak Savannah (LPOS) and Central Post Oak Savannah (CPOS) of Texas, USA, 2004.

\begin{tabular}{|c|c|c|c|c|c|c|}
\hline \multirow{2}{*}{$\begin{array}{c}\text { Habitat } \\
\text { composition }\end{array}$} & \multicolumn{2}{|c|}{ LPOS } & \multicolumn{4}{|c|}{ CPOS } \\
\hline & $\bar{x}$ & SE & $\bar{x}$ & SE & $t$ & $P$ \\
\hline Bottomland timber ${ }^{a}$ & 3.6 & 0.6 & 15.6 & 2.6 & -4.965 & $<0.001$ \\
\hline Total timber & 37.5 & 2.4 & 43.4 & 3.5 & -1.392 & 0.167 \\
\hline Native range & 29.8 & 2.2 & 23.2 & 3.4 & 1.647 & 0.102 \\
\hline Improved pasture & 25.4 & 1.9 & 20.4 & 2.9 & 1.433 & 0.154 \\
\hline HCI & 58.1 & 2.0 & 58.9 & 2.8 & -0.207 & 0.837 \\
\hline
\end{tabular}

${ }^{\mathrm{a}}$ Values for bottomland timber were $\ln +1$ transformed prior to analysis.
Table 4. Land-use priorities ${ }^{\mathrm{a}}$ of landowners in wildlife management associations in the Lower Post Oak Savannah (LPOS) and Central Post Oak Savannah (CPOS) of Texas, USA, 2004.

\begin{tabular}{|c|c|c|c|c|c|c|}
\hline \multirow[b]{2}{*}{ Land-use priorities } & \multicolumn{2}{|c|}{ LPOS } & \multicolumn{2}{|c|}{ CPOS } & \multirow[b]{2}{*}{$t$} & \multirow[b]{2}{*}{$\boldsymbol{P}$} \\
\hline & $\bar{x}$ & SE & $\bar{x}$ & SE & & \\
\hline Wildlife management & 4.6 & 0.1 & 4.7 & 0.1 & -1.792 & 0.075 \\
\hline Relaxation & 4.1 & 0.1 & 4.5 & 0.1 & -2.369 & 0.019 \\
\hline Livestock production & 3.7 & 0.1 & 3.6 & 0.2 & 0.477 & 0.635 \\
\hline Place to live & 4.4 & 0.1 & 3.8 & 0.2 & 3.025 & 0.003 \\
\hline Lease hunting & 1.5 & 0.1 & 2.0 & 0.2 & -2.561 & 0.013 \\
\hline Nonlease hunting & 2.7 & 0.1 & 3.9 & 0.2 & -5.273 & $<0.001$ \\
\hline
\end{tabular}

compared to $\operatorname{CPOS}\left(\bar{x}_{\mathrm{L}}=2.7, \mathrm{SE}=0.1 ; \bar{x}_{\mathrm{C}}=5.3, \mathrm{SE}=0.3\right.$, $t=-7.500, P<0.001)$, but there was no difference in the number of water conservation activities (averaging $<2$ for both regions, $t=0.184, P=0.854$ ).

As we expected, wildlife management was the highest land-use priority across all associations and did not differ between regions (Table 4). Land use for relaxation was about $10 \%$ more important in CPOS, and LPOS landowners rated the importance of their property as a place to live $16 \%$ higher than CPOS. Lease hunting was the lowest priority for all associations, but nonlease hunting was $>44 \%$ more important in CPOS compared to LPOS.

There was no difference in the percentage of land affected by various management practices over the previous 12 month period (Table 5). Although percentage of land affected by the various practices did not differ, rotational grazing was conducted on $>3.5$ times more land in CPOS compared to LPOS, whereas controlled burning and brush control were conducted on over 25 and 4 times more land, respectively. We attribute this to the higher average tract size of CPOS properties, which requires more effort to achieve meaningful results for certain land management activities.

Table 5. Mean area (\% and ha) of land affected by wildlife management activities $^{\mathrm{a}}$ conducted by landowners within wildlife management associations in the Lower Post Oak Savannah (LPOS) and Central Post Oak Savannah (CPOS) of Texas, USA, 2004.

\begin{tabular}{|c|c|c|c|c|c|c|c|}
\hline & & \multicolumn{2}{|c|}{ LPOS } & \multicolumn{2}{|c|}{ CPOS } & \multirow[b]{2}{*}{$t$} & \multirow[b]{2}{*}{$P$} \\
\hline & & $\bar{x}$ & $\mathrm{SE}$ & $\overline{\boldsymbol{x}}$ & SE & & \\
\hline \multirow{2}{*}{ Rotational grazing } & $\%$ & 28.4 & 2.6 & 27.7 & 4.9 & 0.129 & 0.899 \\
\hline & ha & 20.0 & 3.1 & 70.1 & 13.3 & -3.595 & 0.000 \\
\hline \multirow{2}{*}{ Controlled burning } & $\%$ & 2.4 & 0.7 & 2.9 & 1.3 & -0.574 & 0.566 \\
\hline & ha & 0.7 & 0.2 & 17.6 & 9.4 & -2.238 & 0.026 \\
\hline \multirow{2}{*}{ Native plant restoration } & $\%$ & 8.5 & 1.5 & 11.4 & 3.1 & -1.212 & 0.226 \\
\hline & ha & 2.3 & 0.4 & 11.3 & 3.5 & -0.769 & 0.442 \\
\hline \multirow{2}{*}{ Food plots } & $\%$ & 5.5 & 0.9 & 3.6 & 1.1 & 0.473 & 0.637 \\
\hline & ha & 1.7 & 0.2 & 11.6 & 8.0 & -0.321 & 0.748 \\
\hline \multirow{2}{*}{ Brush control } & $\%$ & 11.4 & 1.3 & 7.7 & 1.7 & 0.454 & 0.651 \\
\hline & ha & 7.2 & 1.6 & 33.1 & 10.2 & -2.899 & 0.004 \\
\hline \multirow{2}{*}{ Erosion control } & $\%$ & 6.8 & 1.2 & 4.5 & 2.2 & 1.031 & 0.305 \\
\hline & ha & 3.1 & 1.0 & 12.4 & 6.8 & -0.0608 & 0.543 \\
\hline
\end{tabular}

${ }^{a}$ All categories except rotational grazing were $\ln +1$ transformed prior to analysis. 
Associations in LPOS, on average, had greater longevity in membership $\left(\bar{x}_{\mathrm{L}}=4.1 \mathrm{yr}, \mathrm{SE}=0.1, \bar{x}_{\mathrm{C}}=3.1, \mathrm{SE}=0.2, t\right.$ $=4.598, P<0.001)$ and more regular member meetings than landowners in associations in CPOS $\left(\bar{x}_{\mathrm{L}}=\right.$ twice $/ \mathrm{yr}, \bar{x}_{\mathrm{C}}$ $<$ twice/yr, $t=3.946, P<0.001)$.

\section{Social Capital}

All 3 measures of social capital were lower in LPOS than CPOS, including trust $\left(\bar{x}_{\mathrm{L}}=3.3, \mathrm{SE}=0.1, \bar{x}_{\mathrm{C}}=3.6, \mathrm{SE}=\right.$ $0.1, t=2.198, P=0.029)$, reciprocity $\left(\bar{x}_{\mathrm{L}}=3.0, \mathrm{SE}=0.1, \bar{x}_{\mathrm{C}}\right.$ $=3.4, \mathrm{SE}=0.1, t=-3.339, P=0.001)$, and civic involvement $\left(\bar{x}_{\mathrm{L}}=6.8, \mathrm{SE}=0.3, \bar{x}_{\mathrm{C}}=8.2, \mathrm{SE}=0.7, t=\right.$ $-2.082, P=0.038)$.

In the regression model for all WMAs in LPOS, trust was positively influenced by the time of land ownership, the frequency of meetings, and the proportion of males participating in the association (Table 6). An additional positive influence on trust was the percentage of income from land activities, which appeared in one of the individual WMA models in LPOS. Interestingly, HCI had an important negative effect on trust in the overall model and for half of the individual models in LPOS. The percentage of total timber and the percentage of bottomland timber habitat were also negatively associated with trust in another WMA. Other factors that tended to negatively influence trust in LPOS included residency in a town versus onproperty residence (half of the individual models), and professional compared to agricultural occupation in the POCWMA.

The only important independent variable for trust when modeled for all WMAs in CPOS was the number of members, which was negatively related. Two of the 4 individual WMA models in CPOS did not produce results. Due to the small sample size for ACWMA $(n=2)$, regression analysis was not possible, and we did not identify any relationships explaining trust for $\mathrm{MTBCC}$ as being significant. Other negative influences on trust were HCI and residence in an urban area as opposed to on the property, which each appeared in one individual model. Year born was also negatively related to trust in one association (CCWMA). This indicated that age was positively related to trust in this association, along with 2 other positive variables: the percentage of males in the association, and the years as an association member. These variables, along with whether a member lived in an urban area, accounted for over $99 \%$ of the variation in trust for CCWMA, the highest coefficient of determination value for any model.

\section{DISCUSSION}

Landowners belonging to WMAs in the CPOS were part of much smaller groups than LPOS landowners. They also considered relaxation and hunting more important land uses than LPOS landowners. The CPOS landowners practiced more wildlife management activities, enjoyed higher deer populations, and exhibited higher social capital. Conversely, more LPOS landowners lived on their properties and indicated that rural living was a more important land ownership priority. More than half of the respondents in the LPOS also indicated they held professional positions and, therefore, it is likely that more of these landowners commute to work compared to CPOS landowners. Urban sprawl and commuting have been identified as major factors in the decline of social capital throughout the United States (Putnam 1995, 2000).

Trust within WMAs in LPOS increased with increasing number of meetings, years of property ownership, percentage of males in the association, and decrease in $\mathrm{HCI}$ value. In group management of common pool resources, frequency of contact is important in developing trust relationships and rule compliance (Dietz et al. 2003), and residential stability leads to stronger community ties (Putnam 2000). In terms of gender, males tend to join more formal organizations, whereas females are more likely to enjoy informal relationships among friends (Putnam 2000, Offe and Fuchs 2002). The overall male dominance in WMA membership in CPOS may lead to increased homogeneity and social capital within the group. The negative relationship between HCI and trust in LPOS presents a number of interesting speculations. As HCI increased among WMAs in this area, the estimated density of deer also increased from an average of 2.9 deer $/ \mathrm{km}^{2}$ on BCWMA and POCWMA to $>9.8$ deer $/ \mathrm{km}^{2}$ on TCWMA (M. Longoria, TPWD, unpublished data). It is possible that as deer populations increase, the perceived need for cooperation and social interaction may actually decrease. By contrast, when deer populations decline, it may become imperative for landowners to work more closely together to maintain viable populations. The decrease in social capital with increasing habitat cover may also simply reflect the fact that more timbered habitat is present, which may in turn create visual and psychological barriers to social contact among neighbors.

The smaller membership size associated with larger average tract size in CPOS may be the most important factor that influenced increased social capital in this region. Group size is an important aspect of social capital building because as membership increases it becomes more difficult to develop trust and reciprocity relationships among members (Wuthnow 1994). In CPOS, where group size ranged from 6 to 55 members, WMA membership size was negatively correlated with trust. By contrast, in the LPOS, group size ranged from 91 to 148 members and was not found to be a statistically significant explanatory variable for trust. Therefore, some threshold of group size may exist above which intragroup trust cannot be predicted. Pretty and Ward (2001) noted that most natural resource management groups with effective social capital are small, ranging from 20 to 30 members, whereas Wuthnow (1994) suggested that the ideal group size for maximum trust building is no $\leq 15-20$ people.

Higher deer populations may motivate landowners to shift emphasis away from increasing deer numbers to improving the quality of deer herds, especially the number of males with desirable antler traits. Attaining improved antler quality may require a higher level of cooperation among 
Table 6. Stepwise multiple regression table ${ }^{a}$ for landowners within wildlife management associations (WMAs) ${ }^{\mathrm{b}}$ in the Lower Post Oak Savannah (LPOS) and Central Post Oak Savannah (CPOS) of Texas, USA, 2004. Landowner trust within an association is the dependant variable.

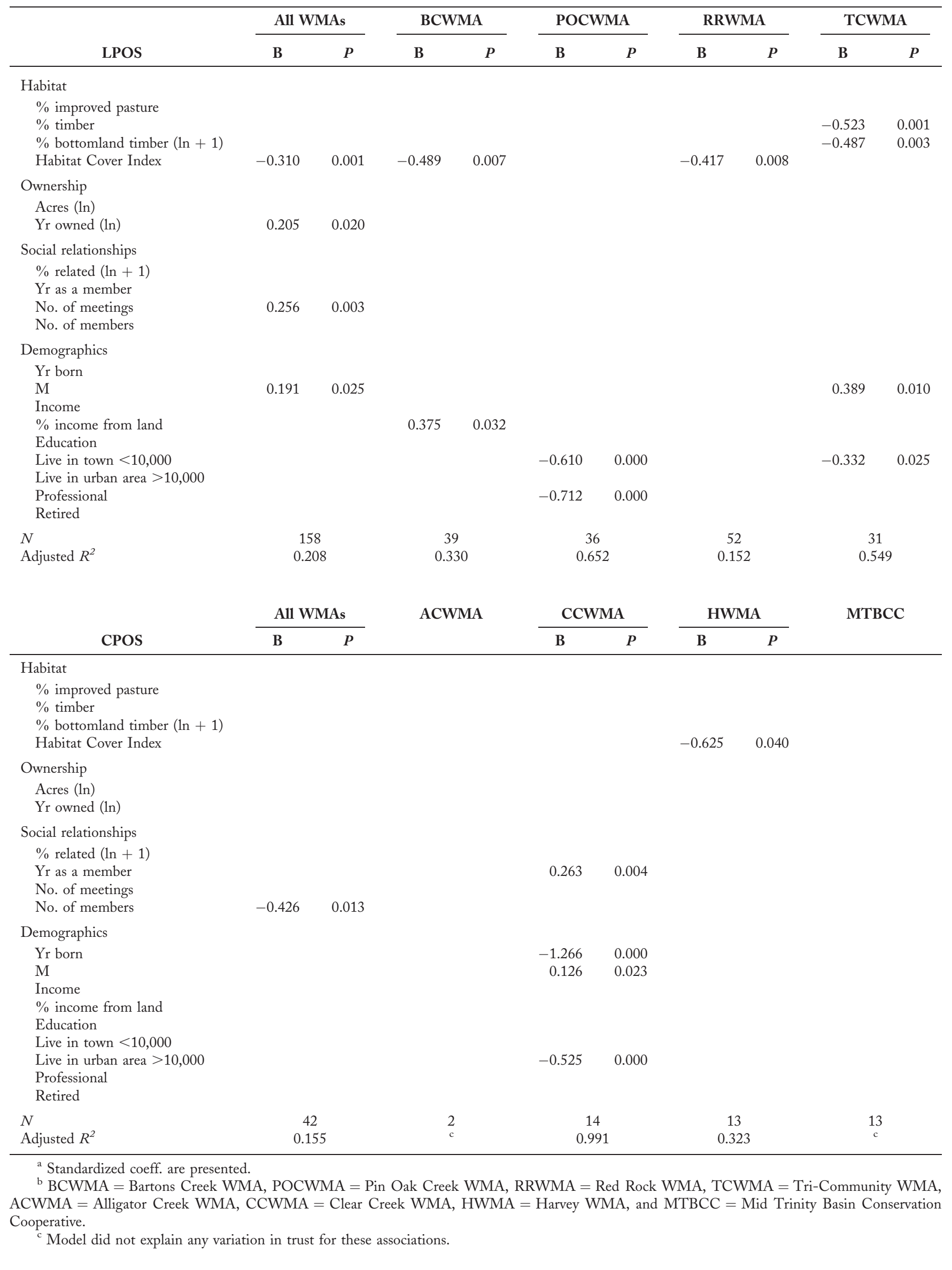


landowners and, thus, enhance social capital rather than simply increasing deer numbers. However, the suggestion that improved deer management in the CPOS is a function of social capital building through WMA membership must be treated with caution because improved management may simply be the product of shared self-interests among a limited number of landowners. As Flora (1998) pointed out, communal management of a shared resource may occur without any altruistic feelings among members. Ostrom (1992) stated that while social capital may still exist within a group, it may be generated from rational choices from selfinterested individuals rather than a product of community bonding. Nevertheless, in the context of coordinated management of common pool resources, interpersonal trust is critical. Therefore, for sustainable use of common pool resources, social capital building remains an important imperative.

\section{MANAGEMENT IMPLICATIONS}

Our results suggest that small $(<30$ members) rather than large $(>100)$ wildlife management associations may be more effective for building social capital. However, this may not be possible in highly fragmented habitats. Where average property size approaches 80 ha per member, it may be possible to restore area-dependent species, such as bobwhite quail (Colinus virginianus), with $\leq 25$ association members, based on an average of about 2,000 ha for a viable population (Texas Quail Council 2005). Incentive programs, such as habitat improvement cost sharing, targeted at WMAs in priority areas, could significantly increase landowner participation and interest in relevant associations. For example, large-scale projects requiring multilandowner collaboration could include native grassland restoration for quail or brush control for enhanced water yields. The different conditions for WMA formation reflect different needs according to land ownership and land-use patterns. Social capital may be generated from the shared values of local landowners, but trust and reciprocity relationships are enhanced through regular contact of association members. When membership exceeds 30 , it may be advantageous to increase the number of association meetings, increase the means of communication, or subdivide into groups in order to increase social capital. In addition to group size, other factors play a role in social capital building among landowners within WMAs. Social capital may be negatively impacted by an increase in absentee landowners or those in distant professional positions who might be less trusting of neighbors than local landowners engaged in agriculture. Another dampening effect on social capital, particularly trust, could be the relative abundance of heavily timbered habitat in an open-pasture-dominated region. The elevated deer densities associated with wooded habitats may decrease the perceived need for landowners to cooperatively improve deer populations. Conversely, in areas with high deer numbers, collective management to improve herd quality may require high levels of trust, which is best achieved in small, homogeneous associations.

\section{ACKNOWLEDGMENTS}

The TPWD and a fellowship with the National Water Research Institute provided funding and support for this research. We extend special thanks to S. Kamata for data entry and editorial assistance. E. Hintze provided statistical assistance, S. Lange provided graphic images, and R. Wagner assisted in the nonresponse bias survey.

\section{LITERATURE CITED}

Anheier, H., and J. Kendall. 2002. Interpersonal trust and voluntary associations: examining three approaches. British Journal of Sociology 53: 343-362.

Babbie, E., F. Halley, and J. Zaino. 2003. Adventures in social research: data analysis using SPSS 11.0/11.5 for windows. Pine Forge Press, Thousand Oaks, California, USA.

Benson, D. 2004. Wildlife as a farm and ranch business. < http://www.ext. colostate.edu/pubs/natres/06514.html>. Accessed 15 Jan 2004.

Benson, D. E., R. Shelton, and D. W. Steinbach. 1999. Wildlife stewardship and recreation on private lands. Texas A\&M University Press, College Station, USA.

Brann, P., and M. Foddy. 1987. Trust and the consumption of a deteriorating common resource. Journal of Conflict Resolution 31:615630 .

Brehm, J., and W. Rahn. 1997. Individual-level evidence for the causes and consequences of social capital. American Journal of Political Science 41: 999-1023.

Bryman, A., and D. Cramer. 1990. Quantitative data analysis for social scientists. Routledge, New York, New York, USA.

Coleman, J. 1990. Foundations of social theory. Belknap Press of Harvard University, Boston, Massachusetts, USA.

Czaja, R., and J. Blair. 2005. Designing surveys: a guide to decisions and procedures. Sage, Thousand Oaks, California, USA.

Daley, S. S., D. T. Cobb, P. T. Bromley, and C. E. Sorenson. 2004. Landowner attitudes regarding wildlife management on private land in North Carolina. Wildlife Society Bulletin 32:209-219.

Dietz, T., E. Ostrom, and P. C. Stern. 2003. The struggle to govern the commons. Science 302:1907-1912.

Dillman, D. A. 2000. Mail and internet surveys: the tailored design method. John Wiley \& Sons, New York, New York, USA.

Dobbs, D. 2004. Private property, public good. Audubon. <http:// magazine.audubon.org/privateproperty.html>. Accessed 15 Feb 2004.

Flora, J. L. 1998. Social capital and communities of place. Rural Sociology 63:481-506.

Foster, J. J. 2001. Data analysis using SPSS for Windows: a beginner's guide. Sage, Thousand Oaks, California, USA.

Halpern, D. 2005. Social capital. Polity Press, Cambridge, United Kingdom.

Hardin, G. 1968. The tragedy of the commons. Science 162:1243-1248.

Hendrix, J. 2002. Landowner cooperatives. Your side of the fence. Oklahoma Department of Wildlife Conservation. <http://www. wildlifedepartment.com/ysof/vol2issue2.PDF > . Accessed 15 Jan 2004.

Higginbotham, B. 1999. Conservation and management of the white-tailed deer: an East Texas perspective. Pages II-D-21-II-D-31 in Proceedings of the symposium on deer management 101. Texas Agricultural Extension Service, 21-23 September, College Station, USA.

Hofferth, S. L., and J. Iceland. 1998. Social capital in rural and urban communities. Rural Sociology 63:574-598.

Jackson-Smith, D. J., U. Kreuter, and R. S. Krannich. 2005. Multidimensionality of property rights orientation evidence from Utah and Texas ranchers. Society and Natural Resources 18:587-610.

Kerr, N. L. 1989. Illusions of efficacy: the effects of group size on perceived efficacy in social dilemmas. Journal of Experimental Social Psychology 25:287-313.

Land Information Systems. 2005. Texas land trends. Texas Cooperative Extension. < http://landinfo.tamu.edu/frag > . Accessed 22 Apr 2005.

Leopold, A. 1936. Farmer-sportsmen set-ups in the north-central region. Pages 279-285 in Proceedings of the 1936 North American Wildlife Conference, 3-7 February 1936, Washington, D.C., USA. 
Leopold, A. 1940. History of the Riley Game Cooperative 1931-1939. Journal Wildlife Management 4:291-302.

Levine, J. M., and R. L. Moreland. 1990. Progress in small group research. Annual Review of Psychology 41:585-634.

Lohr, S. L. 1999. Sampling: design and analysis. Brooks/Cole, Pacific Grove, California, USA.

MacGillivray, A., and P. Walker. 2000. Local social capital: making it work on the ground. Pages 197-211 in S. Baron, J. Field, and T. Schuller, editors. Social capital: critical perspectives. Oxford University Press, Oxford, United Kingdom.

Maloney, W. A., G. Smith, and G. Stoker. 2000. Social capital and associational life. Pages 212-225 in S. Baron, J. Field, and T. Schuller, editors. Social capital: critical perspectives. Oxford University Press, Oxford, United Kingdom.

McPherson, M. 1983. The size of voluntary organizations. Social Forces 61: 1044-1064.

Mississippi State University Extension Service. 2004. Wildlife and forestry landowner cooperatives. <http://msucares.com/pubs/publications/ pub1637.htm $>$. Accessed 15 Jan 2004.

Molm, L. D., N. Takahashi, and G. Peterson. 2000. Risk and trust in social exchange: an experimental test of a classical proposition. American Journal of Sociology 105:1396-1427.

Offe, C., and S. Fuchs. 2002. A decline in social capital? Pages 189-243 in R. Putnam, editor. Democracies in flux: the evolution of social capital in contemporary society. Oxford University Press, Oxford, United Kingdom.

Olenick, K. L., U. P. Kreuter, and J. R. Conner. 2005. Texas landowner perceptions regarding ecosystem services and cost-sharing land management programs. Ecological Economics 53:247-260.

Ostrom, E. 1992. Community and the endogenous solution of commons problems. Journal of Theoretical Politics 4:343-351.

Pretty, J., and D. Smith. 2004. Social capital in biodiversity conservation and management. Conservation Biology 18:631-638.

Pretty, J., and H. Ward. 2001. Social capital and the environment. World Development 29:209-227.

Putnam, R. 1995. Bowling alone: America's declining social capital. Journal of Democracy 6:65-78.
Putnam, R. 1996. The strange disappearance of civic America. The American Prospect (Winter):34-48.

Putnam, R. 2000. Bowling alone: the collapse and revival of American community. Simon and Schuster, New York, New York, USA.

Rottman, S., and J. Powell. 2004. Farm and ranch recreation handbook. RLS International, Cheyenne, Wyoming, USA.

Silverman, R. M., editor. 2004. Community-based organizations: the intersection of social capital and local context in contemporary urban society. Wayne State University Press, Detroit, Michigan, USA.

Stolle, D. 2001. Clubs and congregations: the benefits of joining an association. Pages 202-244 in K. Cook, editor. Trust in society. Russell Sage Foundation, New York, New York, USA.

Telfair, R. C. 1999. Introduction: ecological regions of Texas: description, land use, and wildlife. Pages 1-39 in R. C. Telfair, editor. Texas wildlife resources and land uses. University of Texas Press, Austin, USA.

Texas Parks and Wildlife Department [TPWD]. 2004. Wildlife management associations and co-ops. Texas Parks and Wildlife Department, Austin, USA.

Texas Quail Council. 2005. Where have all the quail gone? Texas Parks and Wildlife Department, Austin, USA.

Tyler, T., and P. Degoey. 1995. Collective restraint in social dilemmas: procedural justice and social identification effects on support for authorities. Journal of Personality and Social Psychology 69:482-497.

United States Department of Agriculture. 1997. Census of agriculture, Texas state and county data. U.S. Department of Agriculture, Washington, D.C., USA

Wagner, M., and U. Kreuter. 2004. Groundwater supply in Texas: private land considerations in a rule-of-capture state. Society and Natural Resources 17:349-357.

Wuthnow, R. 1994. Sharing the journey: support groups and America's new quest for community. Free Press, New York, New York, USA.

Yantis, J. H. 1984. The Lexington-Marquez wildlife unit. Texas Parks and Wildlife Department Federal Aid Series No. 23, Austin, USA.

Associate Editor: Morrison.

Appendix. Survey questions sent in 2004 to landowners in 8 wildlife management areas in the Post Oak Savannah, Texas, USA.

Topic
\begin{tabular}{c} 
Question \\
\hline $\begin{array}{c}\text { Property and land-management } \\
\text { characteristics }\end{array}$ \\
How many acres within your landowner association do you own? \\
How many yr have you or your family owned this acreage? \\
Approx. what \% of your total acreage is comprised of: \\
(1) Nonflooded native rangeland (2) Nonflooded timberland (3) Bottomland timber (4) Bottomland \\
pasture (5) Open-water wetlands (6) Cropland (7) Improved forage pasture (bermudagrass, bahiagrass, K- \\
R bluestem, etc) \\
Indicate your land-use priorities for each category below (5 = very important-1 = very unimportant) \\
(1) Wildlife management (2) Livestock production (3) Farming or hay production (4) Relaxation or leisure \\
(5) Lease hunting (6) Nonlease hunting \\
Indicate the approx. no. of acres affected on your property in the last 12 months by each of the following \\
land management activities: \\
(1) Rotational grazing (2) Controlled burning (3) Native plant restoration (4) Wildlife food plots (5) \\
Mechanical or chemical brush control (6) Erosion control (7) Other \\
Indicate whether you have used the following wildlife management activities on your property in the last 12 \\
months. \\
(1) Pond construction (2) Shallow water impoundment for wildlife (3) Coyote control (4) Feral hog \\
control (5) Fire ant control (6) Deer counts (7) Deer harvest records (8) Selective ad M harvest (9) \\
Selective doe harvest (10) Provide supplemental shelter (brush piles, nest boxes, etc.) \\
Which of the following practices for water conservation do you use? (Check all that apply) \\
(1) Terraces (2) Vegetation management for increased water infiltration (3) Shaped waterways (drainages) \\
(4) Exclude livestock from stream sides (5) Rainwater harvesting (6) Stream side buffer areas (vegetated \\
waterways) (7) Grey water re-use (8) Reseeding with native plants (9) Conservation tillage (e.g., no-till \\
planting, contour planting, etc.)
\end{tabular}


Appendix. Continued.

\begin{tabular}{|c|c|}
\hline Topic & Question \\
\hline \multirow[t]{10}{*}{$\begin{array}{l}\text { Social interaction and civic } \\
\text { participation }\end{array}$} & $\begin{array}{l}\text { How many yr have you been a member of your landowner association? } \\
\text { How often does your landowner association meet? }\end{array}$ \\
\hline & $\begin{array}{l}\quad(1)<\text { once/yr (2) Once/yr (3) Twice/yr (4) } \geq 3 \text { times/yr } \\
\text { Indicate your level of agreement with each of the following statements }(5=\text { strongly agree- } 1=\text { strongly } \\
\text { disagree): }\end{array}$ \\
\hline & $\begin{array}{l}\text { (1) Generally speaking, most people can be trusted (2) I know most of the members of my landowner } \\
\text { association (3) I meet with members of my landowner association outside of assoc activities (4) There are } \\
\text { many members of my landowner association I consider friends (5) I trust members of my landowner } \\
\text { association (6) I would loan equipment to at least one nonkin member of my landowner association (7) I } \\
\text { would loan equipment to any member of my landowner association (8) I would provide personal time to } \\
\text { help at least one nonkin member of my landowner association (9) I would provide personal time to help } \\
\text { any member of my landowner association (10) I would lend money to at least one nonkin member of my } \\
\text { landowner association (11) I would lend money to any member of my landowner association } \\
\text { How involved are you and (or) your spouse (if applicable) in each of the following types of community } \\
\text { organizations? ( } 3 \text { = very involved-0 = not involved) }\end{array}$ \\
\hline & $\begin{array}{l}\text { (1) Church groups (2) Civic organizations (Rotary, Jaycees, Lions, etc.) (3) Athletic or recreation groups } \\
\text { (softball, soccer, card games, etc.) (4) Education or school groups (PTA, boosters, etc.) (5) Youth-oriented } \\
\text { groups (4-H, scouts, etc.) (6) Community government (city, county commissions, etc.) (7) Ranch or farm } \\
\text { organizations (Farm Bureau, Cattleman's Association, etc.) (8) Other }\end{array}$ \\
\hline & Approx. how many of the property owners in your landowner association are you related to? \\
\hline & What is your gender? \\
\hline & What yr were you born? \\
\hline & Where is your primary residence? \\
\hline & $\begin{array}{l}\text { (1) On my property within my association ( } 2 \text { ) Town }<10,000 \text { persons (3) Urban area }>10,000 \text { persons } \\
\text { What is your highest level of formal education? }\end{array}$ \\
\hline & $\begin{array}{l}\text { (1) < high school (2) High school graduate or GED (3) Vocational or technical training (4) Some college } \\
\text { (5) Bachelor's degree (6) Postgraduate degree }\end{array}$ \\
\hline \multirow[t]{4}{*}{ Personal information } & What is your primary occupation? \\
\hline & $\begin{array}{l}\text { (1) Agriculture (Farming or ranching) (2) Professional (3) Retired (4) Other } \\
\text { Select the category that best indicates your average annual household income in 2003: }\end{array}$ \\
\hline & $\begin{array}{l}\text { (1) }<\$ 25,000(2) \$ 25,000-49,999 \text { (3) } \$ 50,000-74,999 \text { (4) } \$ 75,000-99,999(5)>\$ 100,000 \\
\text { Approx. what \% of your average annual household income is derived from activities related to your property } \\
\text { in your landowner association? }\end{array}$ \\
\hline & (1) $<10 \%$ (2) $11-25 \%$ (3) $26-50 \%$ (4) $51-75 \%(5)>75 \%$ \\
\hline
\end{tabular}

